\title{
On the Lagging Legislation of China Tourism
}

\author{
Xiaolin Li \\ College of Management, Xi'an University of Science and Technology \\ Xi'an 710054, China \\ E-mail: fastlxl@yahoo.com.cn
}

Received: March 21, $2011 \quad$ Accepted: July 14, $2011 \quad$ doi:10.5539/ijms.v3n3p194

\begin{abstract}
The lagging legislation of tourism has become a serious obstacle to the continuous development of tourism industry. This paper discusses the explicit facts of lagging legislation of tourism from four aspects: numbers of tourism laws, qualities, procedures of legislation, and mode of legislation. The conclusion is helpful for us recognizing the problems in legislation of China tourism, reforming the laws and regulations of tourism, and making them more suitable for the development of tourism industry.
\end{abstract}

Keywords: Tourism legislation, Lag, Procedures of legislation, Mode of legislation

\section{Introduction}

The legislation of tourism is an output from tourism development. It covers not only developing new tourism laws and regulations, but also amending or abolishing old tourism laws and regulations. Besides, it includes the composition of laws and regulations of tourism as the legal system of tourism is close to perfect.

Since the early days of tourism, China has published no less than four dozen tourism market rules, regulations, and codes, plus some local regulations. Generally speaking, they basically concern all aspects of tourism, including Travel Agency Management Rules, Tour Guide Management Rules, Chinese Citizens Outbound Travel Management Rules, Standard of Grading Tourist Hotel, and Interim Rules for Tour Construction Management. All these rules and regulations have played a role in adjusting tourism structure, regulating tourism market, solving tourism conflicts, and protecting rights and obligations of tourism subjects.

To speed up the legislation of tourism is very important. However, few studies focus on this subject, especially the lagging legislation. Therefore, this paper takes this subject and analyzes the facts of lagging legislation of tourism in China. This paper may have a reference value for improving and completing the legislation of China tourism, promoting the healthy development of China tourism market.

\section{The lag of tourism legislation in quantities}

During the transformation of China economy system, works on the legislation of tourism, especially concerning the regulation of tourism market, are particularly emphasized. Some policies and regulations have been constituted and approved in order to regulate the market subjects, adjust market orders, strengthen and improve macro control, build and complete tourism market system, and drive an overall development of tourism. However, laws in these fields are still an empty. Relevant laws and institutions can not be released in time. The Law of Tourism, as the Constitution of tourism industry, is still excluded from the national legislation plan. Besides, present laws in valid have no sufficient supportive regulations and rules in application. And not a complete legal system is ready. In detail:

\subsection{The blank of basic tourism law and special tourism law}

The basic tourism law, as the "Constitution" of tourism law system, is the origin and basis of tourism legislation at all levels. The basic tourism law not only has significant meanings for the construction and development of tourism law system, but also has a directive and regulatory meaning for the general development of tourism industry in China. However, since the establishment of China, we have not developed a comprehensive systematic basic tourism law or any special tourism law. The absence of basic tourism law makes the legislation of tourism in China in a rudderless state. As a result, local tourism lawmaking activities have no principles to follow. This fact is also one of important reasons for the disorder of tourism market at present. 


\subsection{The national legislation of tourism is few and at a low level, and the tourism law system is not complete.}

Although China has extremely focuses on the construction of legal system since the reform and opening up, there is not any special law adjusting the relationship of tourism parties. Only three administrative regulations issued by the State Council and only six rules issued by the National Tourism Administration are used to adjust the relationship of tourism parties. Generally speaking, current regulations and rules do not concern the principles and the measures of developing the tourism industry at a national level. They can not effectively restrict or adjust the relationship of tourism parties. Therefore, in China's tourism law system, the laws, administrative regulations, and department rules, as social public products, are in an extreme short in quantities. The legislation of tourism is still at a lower level. Besides, some existing administrative regulations and department rules are outdated, with simple contents, and without practical values.

\section{The lag of tourism legislation in quality}

The lag of tourism legislation in quality is mainly as follow:

3.1 More outdated and conservative policies and regulations, but less prospective and advanced policies and regulations.

Current valid regulations and rules, especially some rules concerning tourism supervision and macro adjustment, are marked with traces of times. They can not fit the needs at present.

Take the Travel Agency Management Rules for example. Firstly, it is the establishment of domestic travel agencies in China. Travel agency is an important carrier ensuring the normal performance and operation of tourism business, leading the tourism industry. Problems in the establishment of domestic travel agencies are derived from the Travel Agency Management Rules, issued by the State Council on Oct. 1996. It regards the travel agency as a franchise industry and regulates that its establishment merely needs fixed business places, necessary business facilities, qualified employees, no less than 300,000 RMB as registered funds, and 100,000 RMB as quality insurance. These requirements were suitable for economic development ten years ago. Today, with the fast development of market economy, and the global market of tourism industry, these conditions seem to be insufficient, far lagging behind the requirement of the times. Among annually increasing travel agencies in China, lots of them are small, with low economic benefits. Because of limited employees, money, and materials, these small travel agencies seldom invest in the design or the development of new products. As a result, they just sell outdated products, without any special feature. Then, they actually delay the development of whole tourism market.

Firstly, it is the operation of international travel agencies in China. The Travel Agency Management Rules regulates that international travel agency shall not engage in tourism business in China. Only after being approved by National Tourism Administration, they can set up offices for consultant, liaison, and publicity. This provision significantly restricts the entry of foreign travel agencies into China market, harming the development of foreign travel agencies in China. Too many restrictions on foreign travel agencies are proper for today's tourism market, what is not good for the competition or the development of domestic tourism industry, the update of tourism operation ideas, or the communication of tourism management experiences.

3.2 More regulations are used to adjust vertical legal relationships, but few are used to adjust parallel legal relationships.

Current tourism laws and regulations more focus on the supervision and control over tourism enterprises' behaviors, seldom on the legal relationships of tourists and travel agencies, or the legal relationships of travel agencies and other tourism firms. They extremely emphasize on administrative powers. Actually, too much emphasis on administrative power may give administrative organs certain privilege over laws.

For example, some administration organs that make up relevant tourism laws and regulations supervise travel agencies rather than guide or regulate them. Many different administrative organs regulate travel agencies at the same time, what makes the travel agency management a mess. Besides, the professional self-disciplinary organization, such as travel agency association, does not exist in China at present. It is a big regret for the legislation of tourism in China.

3.3 Present tourism laws more focus on punishing tourism enterprises or employees, but few on the services of administrative organs in tourism department.

Provisions from present tourism laws mostly concern the legal consequences and the punishment on the condition of a tourism enterprise violating the laws, but few about how tourism administrative organs create opportunities for travel agencies, or how to provide convenient services for people. Obviously, it is hard to adapt 
to the change of government functions and the achievement of becoming a tourism power.

Take the newly-revised Regulations for Scenic Area for example. The new regulations become valid on $1^{\text {st }}$ Dec. 2006. According to the Regulations, for illegal activities that seriously damage scenic resources, the administrative organs can stop the subjects from illegal activities, ask them to repair or dismantle illegal buildings, and confiscate illegal income. And collect a fine from 500,000 RMB to 1,000,000 RMB. The revision increases the punishment then the original. However, there are still no regulations concerning the services of administrative organs. It indicates that the legislation of tourism in China is still dominated by the principle of punishment.

\subsection{More regulations are principles, but few concern details.}

Many tourism laws and regulations are general and abstract. They can not serve as guidance in practice, such as Provisions for Tourism Safety Management, Regulations on Insurance Responsibility of Travel Agency, Rules for Tourism Hotel Safety, and Assess and Grade Travel Hotel in China, issued by National Tourism Administration. In all these regulations, some items just generally regulate certain travel activity. But in practice, they are useless. That is another problem in the legislation of tourism in China.

3.5 More regulations concern practical objects, but few focus on procedures.

For a long period, China has focuses on the building of substantive laws, regulating the values and goals of state administrative activities and their relevant duties and powers, but seldom on the ways, methods, means, and procedures for administrative organs realizing the management goals, or the rights and obligations of tourism parties in economic activities, and the citizen involvement system reflecting the principle of equality, fairness, and publicity. In other words, the legislation of tourism in China has no emphasis on procedures of tourism law execution and legal procedures of adjustment of market subjects. Even for some valid laws concerning procedures of dealing with tourism accidents, there are many problems, such as the incomplete contents, the disordered forms, the too-general provisions, and the lack of practical values. All these problems make some tourism laws and regulations fail to be implemented or enforced. The phenomenon of emphasizing on substantive laws instead of procedures breaks the balance and unity of legal system, betraying the rational requirement of laws.

\section{The lag of tourism legislation procedures}

Tourism law covers various interests, what may develop kinds of opposite relationships and connected relationships. The distribution of interests relates to the behavioral orientation of interest subjects. Therefore, improving the transparency of tourism legislation, absorbing suggestions of the public widely, and promoting the democracy of tourism legislation procedures are especially important. However, the tourism legislation of China is marked with some traces of planned economy in a sense. It means the legislation of China has a strong color of administrative powers. Legislation procedures include planning, drafting, coordinating and negotiating, examining and confirming, and publicizing. All these procedures happen in administrative organs. Citizens seldom play a role in it. Although the Legislative Law regulates that during the process of legislation, the office should widely collect the suggestions from related agencies, organizations, and citizens. Unfortunately, it does not carry out effectively in practice, because of the lack of specific procedures.

\section{The lag of tourism legislation mode}

The tourism legislation mode refers to the unity of guiding ideology, institutional construction, and theory basis. In detail, it includes the level of tourism legislation, the scope of tourism legislation, and the systematic nature of tourism legislation.

In recent years, the work of tourism legislation in China speeds up and the number of tourism laws rises. Tourism laws and regulations begin to play a more and more important role in practice. However, we can not deny a fact: the tourism legislation of China does not make any essential institutional innovation along with the transformation of economic system. Its guiding ideology, institutional construction, and theory basis still follow the path of traditional legislation, under the dominance of traditional legislation ideology. Not any multi-leveled comprehensive empirical study concern specific tourism legislation. No scientific design or institutional application for some serious theoretical and practical issues, such as the right limits of tourism legislation, the internal procedures of tourism legislation, the procedures of citizen participation, and the systematic legislation of tourism, etc. The legislation of tourism is disturbed by sector protectionism and local protectionism. Sometimes, local tourism policies suffer from the speed of release. Without sufficient investigation and research on interest parties in tourism industry, the implementation of laws and regulations confronts numerous difficulties. As a result, laws are nothing but a decoration. 
The lag of tourism legislation mode can not match with the complexity of tourism composition, the diversity of industry management, and the diversification of tourism law. Therefore, whenever there is a problem emerged in touring activities, we could do nothing but rush into a solution. We can solve the problem by means of institutional coordination under the direction of systematic theory. The useless legislation mode costs a lot but easy to trigger various bad results, such as low efficiency, independent action, and even conflicts, damaging the coordination and order of laws.

\section{Conclusion}

Practices prove that a fast and healthy development of tourism industry of China does not exist without a favorable legislative environment. Here, the key is the publicity of basic tourism law and the improvement of tourism law system. By studying the lag of tourism legislation in China, this paper finds out the problems in the legislation of tourism, which may be helpful to the healthy and orderly development of China tourism industry. Due to limited space, how to make a change for problems mentioned in this paper will be discussed in another one.

\section{References}

Cao, Yang. (2000). The impact of lawmaking lagging on China's tourism industry. Tourism Science, No.2.

F. V. K. raav. (1993). Tourism, Hotel, and Catering Industries EC.

J. D. Goodwin. The Laws of Hotel, Hospitality and Tourism.

Jiao, Chenghua. (1998). Course of Tourism Law. Beijing: Higher Education Press.

Li, Li. (1996). On the uniqueness of hotel legal relationship ------ and the necessity of hotel lawmaking. Tourism Tribune, No.3.

Qi, Xuepeng, \& Yao, Yuping. (1999). A theoretical thought on parallel development of tourism market. Tourism Tribune, No.1.

Qi, Ying. (1997). Problems in Chinas' tourism lawmaking. Tourism Tribune, No.6.

S. medlik. (1993). Dictionary of Travel, Tourism and Hospitality. Oxford: Butter worth-Heinemann.

Wang, Jian. (1997). On the legal environment of China tourism. Nankai Economic Studies, No.1.

Wang, Jian. (1998). Theory and Practice of Tourism Law. Tianjin: Nankai University Press.

Wang, Jinkui. (1996). Course of Tourism Law. Beijing: Tourism Education Press.

Zhang, Cheng. (2001). An initial analysis of foreign lawmaking of tourism.

Zhang, Shumin. (2001). A new thought on macro lawmaking of tourism. Tourism Research, No.8. 